\title{
Assessment of Municipal Organic Solid Waste, as a Potential Feedstock for Briquette Production in Kampala, Uganda
}

\author{
Richard Basona Abondio',2, Allan John Komakech', Robert Kyeyune Kambugu', \\ Nicholas Kiggundu ${ }^{*}$, Joshua Wanyama ${ }^{1}$, Ahamada Zziwa1', Samuel Kyamanywa ${ }^{3}$ \\ ${ }^{1}$ Department of Agricultural and Biosystems Engineering, Makerere University, Kampala, Uganda \\ ${ }^{2}$ Department of Agricultural Engineering, University of Juba, Juba, South Sudan \\ ${ }^{3}$ Department of Agricultural Production, Makerere University, Kampala, Uganda \\ Email: *kiggundu@caes.mak.ac.ug, rich.abondio@gmail.com, allankoma@caes.mak.ac.ug, kambugu@caes.mak.ac.ug, \\ wanyama2002@caes.mak.ac.ug,engzziwa@gmail.com,skyamanywa@gmail.com
}

How to cite this paper: Abondio, R.B., Komakech, A.J., Kambugu, R.K., Kiggundu, N., Wanyama, J., Zziwa, A. and Kyamanywa, S. (2020) Assessment of Municipal Organic Solid Waste, as a Potential Feedstock for Briquette Production in Kampala, Uganda. Journal of Sustainable Bioenergy Systems, 10, 62-75.

https://doi.org/10.4236/jsbs.2020.102006

Received: April 15, 2020

Accepted: May 29, 2020

Published: June 1, 2020

Copyright $\odot 2020$ by author(s) and Scientific Research Publishing Inc. This work is licensed under the Creative Commons Attribution International License (CC BY 4.0).

http://creativecommons.org/licenses/by/4.0/

(c) (i) Open Access

\begin{abstract}
The current shortage of energy resources coupled with environmental degradation problems resulting from deforestation in Uganda has contributed to increased demand for renewable energy resources including municipal organic solid waste and agricultural residues. However, organic waste from Municipal Solid Waste (MSW) may contain contaminants that are harmful to public health and the environment. This study determined the heavy metal concentration in MSW in Kampala City, Uganda. Also, the physicochemical properties of briquettes produced from the MSW were compared with charcoal. The waste samples were collected from residential, institutional and market areas over a period of two weeks. They were then analyzed for the presence of heavy metals. Briquettes were made from the bio-waste and were subjected to calorific and proximate analysis. Results indicated that the mean concentrations of $\mathrm{Cd}, \mathrm{Cr}, \mathrm{Cu}, \mathrm{Fe}$, and $\mathrm{Pb}$ were $1.25 \mathrm{mg} / \mathrm{kg}, 2.04 \mathrm{mg} / \mathrm{kg}, 38.2$ $\mathrm{mg} / \mathrm{kg}, 3.97 \mathrm{mg} / \mathrm{kg}$ and $1.99 \mathrm{mg} / \mathrm{kg}$ respectively while $\mathrm{Hg}$ was not detected. The calorific values of briquettes ranged from 8.9 to $15.3 \mathrm{MJ} / \mathrm{kg}$ and were lower than those of charcoal. Heavy metal concentrations in bio-waste collected were below the permissible acceptable limits. These findings indicate that the sampled MSW does not pose a health hazard arising from the presence of such heavy metals and therefore could be a safe source of renewable energy.
\end{abstract}

\section{Keywords}

Organic Waste, Heavy Metal Concentration, Briquettes, Calorific Value, Renewable Energy 


\section{Introduction}

The rapid population growth, urbanization and economic development in many sub-Sahara African countries such as Uganda have increased resource consumption and waste generation [1]. This has led to increased environmental contamination in mainly urban centers. In Uganda, Kampala city is faced with a crisis of municipal solid waste (MSW) management [2] [3] [4]. With a waste generation rate of between 0.5 to $1.2 \mathrm{~kg} /$ capita/day [5], an estimated 1000 tons of waste is generated per day. According to [3], over $90 \%$ of this waste is organic in nature. However, about $60 \%$ of this waste remains uncollected [3] [4] and is dumped in illegal places causing health and environmental problems [2] [3]. [6] observed that this uncontrolled dumping and mismanagement of MSW leads to the accumulation of heavy metals in the environment. However, municipal organic solid waste is a potential energy resource that can alleviate the pressure on conventional biomass sources in meeting the energy demand of Kampala City [7]. According to [3] and [5], over 28,000 tons of potential feedstock are available for energy generation from Kampala's municipal waste per month. Despite this, the concentration level of hazardous heavy metals in this bio-waste is unknown. Thus, it is not known how suitable the organic wastes are for use as a feedstock for briquette production. These hazardous wastes, if present in significant quantities in the MSW, may pose a threat to potential consumers of the briquettes through endangering their health [8] [9]. Therefore, this study investigated the hazardous heavy metal content in municipal organic solid waste of Kampala City. This was done to assess the suitability of such waste as a feedstock for domestic fuel briquette production.

\section{Materials and Methods}

\subsection{Study Area}

This study was carried out in Kampala, the capital city of Uganda with a total area of about $189 \mathrm{~km}^{2}$ [10]. The estimated population of Kampala is over 1.51 million [11] and is characterized by rapid urbanization, and low standards of living in especially its slums and other informal settlements. Kampala district, which is under the jurisdiction of Kampala Capital City Authority (KCCA), is divided into five divisions. These are: Central; Nakawa; Makindye; Kawempe, and Rubaga.

\subsection{Sampling Procedures}

Waste samples were randomly picked from residential areas, educational and market places within Kampala city. Makerere and Kyambogo universities were selected to represent the educational institutions while Nakasero and Kalerwe markets represented market places. Residential waste was picked randomly from different households across Kawempe and Nakawa divisions.

At the sampling sites, organic waste components were identified and sorted manually. Thirty-six (36) samples of well-mixed organic waste each weighing 10 
$\mathrm{kg}$ were randomly collected from the six different places as mentioned previously. Polythene plastic bags used to carry the waste samples, were sealed properly for safe transportation. The experiment was repeated for a period of six days selected from two consecutive weeks i.e. three days randomly selected from each week. The collected waste samples were transported to Makerere University Agricultural Research Institute Kabanyolo (MUARIK) for sun drying and briquette production. Sun-drying was done for two weeks. This reduced the moisture content of waste samples to about $15 \%$ wb.

\subsection{Sample Preparation}

\subsubsection{Sample Preparation for Heavy Metal Analysis}

One kg of each sun-dried organic waste sample was taken to Makerere University, Soil Sciences Laboratory for hazardous heavy metal analysis. The samples were however first placed in an oven where they were dried at $60^{\circ} \mathrm{C}$ until no change in weight of the samples was noticed, as recommended by [3].

\subsubsection{Preparation of Carbonized Briquettes from Waste Samples}

The carbonization of organic solid waste was done at MUARIK using slow pyrolysis in a steel batch reactor as described by [12]. The procedure was as follows: $5 \mathrm{~kg}$ of sun-dried waste samples were fed into the batch reactor. The reactor was then heated to temperatures ranging from $350^{\circ} \mathrm{C}-600^{\circ} \mathrm{C}$ for $180-240$ min (Variations in temperature and time is due to non-homogeneity of the waste samples). The samples were then removed and crushed into powder using grinding machine (Christy hunt machine with Brook Crompton Series 2000AC Electric Motor Starters) before being sieved using a sieve of $1.5 \mathrm{~mm}$ in size. Adhesives (cassava and molasses which are the commonly used binders) were then mixed with carbonized powder samples $(1.5 \mathrm{~kg}$ each) in a container. The mixing ratios used were Char:Cassava flour:Water $(1.5 \mathrm{~kg}: 0.75 \mathrm{~kg}: 2 \mathrm{~L})$ and Char:Molasses:Water (1.5 kg:750 mL:2 L) [13]. Briquettes were then produced using a hydraulic hand press machine (OMEGA 25 Ton Shop Press Serial No. 40253) before being sun-dried for a week.

\subsection{Laboratory Analysis}

\subsubsection{Heavy Metal Content}

The concentration levels of $\mathrm{Cd}, \mathrm{Cr}, \mathrm{Cu}, \mathrm{Fe}, \mathrm{Hg}$ and $\mathrm{Pb}$ in organic waste samples collected from different areas were determined. The laboratory procedure as proposed by [14] was followed in the heavy metal analysis. In the procedure, the dried samples were ground into a powder using a mixer grinder (Geerpas Industries, Model GSB 1624) to yield a representative homogenous sample. One gram of the representative sample, measured using an Electronic Compact Scale (model SF-400C) was put in a digestion tube. Acid mixture reagent [Conc. $\left.\mathrm{HNO}_{3}+\mathrm{Conc} \mathrm{HCl}(1: 3)\right]$ of nitric acid and hydrochloric acid (aqua regia) was used for the digestion process. The samples in the digestion tubes were then dried at $80^{\circ} \mathrm{C}$. After drying was complete, the resulting solution was removed 
from aluminum block digester, and cooled down. It was then diluted with $50 \mathrm{~mL}$ distilled water to obtain the metal ions of interest. A standard (Fisher Scientific) was introduced to the digested samples, filled in vials. The concentrations of metal ions $[\mathrm{Cd}, \mathrm{Cr}, \mathrm{Cu}, \mathrm{Fe}$, and $\mathrm{Pb}$ ] were then determined using Microwave Plasma Atomic Emission Spectrometer (MP-AES) (Agilent Technologies, SPS 4 Autosampler, Model No. G8410A) together with Inductively Coupled Plasma Mass Spectrometry (ICP-MS) (EDX1800B Desktop XRF).

\subsubsection{Physico-Chemical Properties of Briquettes}

The physicochemical properties of briquettes analyzed included the calorific value, moisture content, volatile matter, ash content and fixed carbon. The procedure followed in their determination is as shown below:

\section{Calorific Value}

A C2000 IKA Digital bomb calorimeter was used to determine the heating value of fuel briquette as was specified by [15] as follows: a sample weighing one gram was placed in a crucible inside a bomb calorimeter that had been pressurized with oxygen. The sample was ignited and burned completely. The calorific value was calculated using Equation (1).

$$
\left.C V=\left(\left(M_{w}+M_{g}\right) \times\left(T_{2}+T_{1}\right)\right)\right) / X
$$

where: $C V=$ calorific value $(\mathrm{kJ} / \mathrm{kg}), M_{w}=$ mass of water placed in the calorimeter (g), $M_{g}$ = water-equivalent weight of the apparatus (g), $T_{1}=$ initial temperature of water in the calorimeter $\left({ }^{\circ} \mathrm{C}\right), T_{2}=$ Final temperature of water in the calorimeter $\left({ }^{\circ} \mathrm{C}\right)$ and $X=$ Mass of fuel sample taken in the crucible $(\mathrm{g})$.

\section{Moisture Content (Mc)}

The procedures as used by [16] were followed in determining the moisture content of briquettes. Equation (2) was then used to calculate its moisture content (dry basis).

$$
M_{c}=\left(\left(W_{A}-W_{d}\right) / W_{A}\right) \times 100 \%
$$

where: $M_{c}=$ Moisture content (\%), $W_{A}=$ Weight of wet briquette in $\mathrm{kg}, W_{d}=$ Weight of oven-dried briquette in $\mathrm{kg}$.

\section{Volatile matter, ash content and fixed carbon}

The methodology as followed by [17] was used to determine the volatile matter, fixed carbon and ash content of the biofuel briquettes. The Equations (3)-(5) show how these parameters were calculated.

Volatile Matter (VM) \%

The percentage of the volatile matter was calculated using Equation (3).

$$
V_{m}=\left(\left(W_{d}-W_{w}\right) / W_{d}\right) \times 100 \%
$$

where: $V_{m}=$ volatile matter content (\%), $W_{d}=$ weight of dry fuel $(\mathrm{g}), W_{w}=$ weight of fuel after (7) seconds (g).

Approximate Ash Content

Equation (4) was used to determined ash content (\%). 


$$
\operatorname{Ash}=\left(W_{a s h} / W_{d}\right) \times 100
$$

where, $W_{\text {ash }}=$ weight of the ash $(\mathrm{kg}), W_{d}=$ weight of dry fuel $(\mathrm{kg})$.

\section{Fixed Carbon Content \%}

The fixed carbon was calculated by subtracting the sum of the percentage of moisture content, volatile matter and ash content from 100, Equation (5) was used.

$$
F C=100-\left(M_{c}+V_{m}+A s h\right)
$$

where, $F C=$ fixed carbon, $V_{m}=$ volatile matter (\%), $M_{c}=$ Moisture content (\%) and $A s h=$ ash content (\%).

\subsection{Data Analysis}

Descriptive statistics for heavy metals concentration and physicochemical characteristics of fuel briquettes were obtained using $\mathrm{R}$ software. One-way analysis of variance (ANOVA) tests was used at $\mathrm{p} \leq 0.05$ to establish any differences in parameters measured. Where significant differences were detected, the Tukey test was used to further ascertain statistical significance between groups.

\section{Results and Discussion}

\subsection{Heavy Metal Content}

Results indicated that different heavy metals were present in organic waste samples except for mercury (Table 1). Cadmium and lead concentration (1.25 and 1.99) $\mathrm{mg} / \mathrm{kg}$ respectively were present only in organic waste samples collected from educational institutions. The concentrations are below the maximum acceptable limits recommended [14] [17] [18] [19]. Thus, organic waste from the study area is safe enough to be used for bioenergy production. The organic waste from residential areas contained the highest concentration of copper followed by market places (Table 1). However one-way ANOVA showed that there was no significant difference $(\mathrm{p}>0.05)$ between the heavy metal content in organic waste from the different places (Table 1).

[6] [20] [21] noted that some heavy metals originate from crops planted around the contaminated wetlands, MSW dumpsites, and water bodies. Also, the uncontrolled disposal of industrial waste in especially the water channels contributed to the presence of heavy metals like $\mathrm{Cu}, \mathrm{Cd}, \mathrm{Fe}, \mathrm{Pb}$, and $\mathrm{Cr}$ in the environment [6].

Table 1. Concentration of heavy metals in organic waste collected from dumpsites $(n=6)$.

\begin{tabular}{ccccccc}
\hline \multirow{2}{*}{ Treatment $^{\mathrm{y}}$} & \multicolumn{6}{c}{ Heavy metal concentration levels $(\mathrm{mg} / \mathrm{kg})$} \\
\cline { 2 - 7 } & $\mathrm{Pb}$ & $\mathrm{Cr}$ & $\mathrm{Cd}$ & $\mathrm{Cu}$ & $\mathrm{Fe}$ & $\mathrm{Hg}$ \\
\hline Residential & $0.00 \mathrm{a}$ & $0.12 \mathrm{a}$ & $0.00 \mathrm{a}$ & $38.2 \mathrm{a}$ & $2.67 \mathrm{a}$ & 0.0 \\
Market & $0.00 \mathrm{a}$ & $0.10 \mathrm{a}$ & $0.00 \mathrm{a}$ & $31.9 \mathrm{a}$ & $1.63 \mathrm{a}$ & 0.0 \\
Educational & $1.99 \mathrm{a}$ & $2.04 \mathrm{a}$ & $1.25 \mathrm{a}$ & $30.2 \mathrm{a}$ & $3.97 \mathrm{a}$ & 0.0 \\
\hline
\end{tabular}

y. Means with same letter, columns wise, indicate no significant difference $(\mathrm{p} \leq 0.05)$ among treatments, $\mathrm{n}=$ number replicate per sample. 
Therefore responsible governmental bodies must enforce regulations governing the disposal of industrial waste and farming in sensitive urban wetlands. Table 1 also shows that the educational institutions' organic waste had a relatively higher concentration of the other heavy metals aside from copper compared to the other areas. According to [22], indoor dust generated by the adult population is a possible source of $\mathrm{Pb}$ and $\mathrm{Cd}$ contamination. It is therefore likely that the larger quantity of dust generated by the higher population in educational institutions could explain the unusually higher content of $\mathrm{Pb}$ and $\mathrm{Cd}$ found in its waste. [23] carried out a study in Nigeria that reported higher levels of heavy metals in MSW compared to this study. This may be because their study assessed MSW at the landfill and the continuous buildup of heavy metals therein could probably have contributed to high concentrations observed compared to this study.

Organic waste from the different areas contained a higher concentration of copper (Table 1). A study by [24] reported a higher concentration of $\mathrm{Cu}$ (40.4 $\mathrm{mg} / \mathrm{kg}$ ) in crops around the Lake Victoria basin. Their explanation for this was that the higher concentration of the metals in soil could have led to higher levels in the crops cultivated around the area. The origin of the heavy metals in the soil could be due to poor waste management and lack of appropriate disposal of industrial, agricultural and residential waste in urban places, which are dumped in wetlands and lake Victoria shores [6].

\subsection{Physico-Chemical Properties of Briquettes}

\section{Calorific Value}

Table 2 shows the mean calorific values of the different briquettes and charcoal. Generally charcoal had a higher calorific value $(\mathrm{p}<0.05)$ compared to the briquettes produced from organic waste. Table 2 also shows that the educational institutions' waste briquette had a higher calorific value compared to the briquettes derived from the market and residential organic waste. However, there was no significant difference ( $p>0.05$ ) between it and the former (Table 2). Also, there was no significant difference $(\mathrm{p}>0.05)$ between the calorific value of briquettes bound with different binders. According to [3], the organic waste collected from Kampala had a gross energy content of $17.3 \mathrm{MJ} / \mathrm{kg}$ a value that is similar to the one obtained in this study.

Table 2. The mean calorific value of cassava binder, molasses binder briquette, and charcoal $(n=3)$.

\begin{tabular}{cccc}
\hline \multirow{2}{*}{ Treatment $^{\mathrm{y}}$} & \multicolumn{3}{c}{ Calorific value $\mathbf{M J} / \mathbf{k g}(\mathbf{n}=3)$} \\
\cline { 2 - 4 } & Briq_cassava & Briq_molasses & Charcoal \\
\hline Residential & $8.90 \mathrm{a}$ & $9.58 \mathrm{a}$ & $28.52 \mathrm{a}$ \\
Market & $15.26 \mathrm{~b}$ & $14.70 \mathrm{~b}$ & $28.52 \mathrm{a}$ \\
Educational & $13.29 \mathrm{~b}$ & $13.17 \mathrm{~b}$ & $28.52 \mathrm{a}$ \\
\hline
\end{tabular}

y. Means with same letter, columns wise, indicate no significant difference $(\mathrm{p} \leq 0.05)$ among treatments, $\mathrm{n}=$ number replicate per sample. Where, Brq_cassava = cassava bound briquette, ${ }^{\star}$ Brq_molasses $=$ molasses bound briquette. 
The calorific values of bio-waste briquettes produced satisfied what was recommended by [25] for fuel briquettes. A similar study by [16] noted that the gross calorific values (GCV) of rice husk briquettes in Uganda ranged between $12.77 \mathrm{MJ} / \mathrm{kg}$ and $14.54 \mathrm{MJ} / \mathrm{kg}$. [26] also found that the calorific values of mango organic waste briquettes ranged between $15.1 \mathrm{MJ} / \mathrm{kg}$ and $16.14 \mathrm{MJ} / \mathrm{kg}$, depending on the type of binder used. According to [27], the specific heating density and combustibility of fuel briquette could be upgraded with the addition of between $10 \%-20 \%$ very fine char items such as charcoal or coal into the briquette. However, the briquettes made of organic waste from educational institutions had higher calorific value compared to the findings by [16] for rice husk and were similar to briquettes from mango organic waste as reported by [26]. Also, briquette from the market waste had a similar calorific value with the findings by [16] for rice husk briquette in Uganda. The better performance of this briquette is maybe due to the mixed types of organic waste generated in education institutions, for instance, paper waste which is a forest by-product, yard waste, and others. Also, a similar finding was reported by [3].

The briquettes produced using cassava and molasses binders had their calorific values varying between $8.90-15.26 \mathrm{MJ} / \mathrm{kg}$. However according to [25], a commercial fuel briquette should have a calorific value greater than $17.5 \mathrm{MJ} / \mathrm{kg}$. This implies that organic waste briquette produced cannot be satisfactorily used as an alternative energy source. Also, their heating values were lower than that of fossil fuels like kerosene (46.5 MJ/kg), natural gas (37.3 MJ/kg) and hard coal $(31.80 \mathrm{MJ} / \mathrm{kg})$ [28]. Despite this, if they are sorted and more combustible fractions are selected then they have the potential to be an important source of energy. This is because of their sustainability as well as other enormous environmental benefits [29].

\subsection{Proximate Analysis of Organic Waste Briquettes}

\subsubsection{Moisture Content}

The average moisture content of charcoal, organic waste briquettes bound with cassava and molasses binders are shown in Table 3. Charcoal had the highest moisture content of $8.12 \%$ followed by briquettes made from market organic waste with molasses binder of $4.65 \%$ and the lowest was observed in briquette made from residential waste bounded with molasses. One-way ANOVA showed that there was a significant difference $(p<0.05)$ between the moisture content briquettes and charcoal. However, there was no significant difference $(p>0.05)$ in moisture content between the different briquettes. According to [30], the low moisture content in briquettes enables proper handling during storage and transportation. The lower moisture content of the briquettes can be attributed to the design and size of molders used to produce briquette. Several studies recommended that quality briquette contains moisture content ranging between $10 \%$ to $15 \%$ [31] [32] [33]. However, the organic waste briquettes, as well as charcoal, have moisture contents below the recommended value. The briquette made of market waste had the highest moisture content compared to briquettes 
from other areas. Also, the study by [26] reported higher moisture content of $11.9 \%$ for briquette compared to current study findings. According to [26], the chemical bonded within the materials and binders used had a high effect and some with higher water holding capacity. However, [34] observed a lower moisture content (2.04\%) from Buffing Dust (BD) briquettes compared to the current study. Furthermore, [32] noted that the briquette with high moisture content had low bulk densities and became more fragile during handling. Generally, the moisture content of the briquette determines the quality and burning characteristics of that briquette. The briquettes with low moisture content will be easily ignited during burning and higher heating values are expected from the fuel [35]. However, the briquettes with higher moisture content will use much of the heat to evaporate the excess water [36], thus causing a lower burning rate and less heat is generated with too much smoke emitted.

\subsubsection{Volatile Matter and Ash Content}

The results of the volatile matter in the different fuels are as shown in Table 3. On average the volatile matter from the Briquettes was $25.0 \%$ while that of charcoal was $22.0 \%$. However, these differences were not significant ( $p>0.05)$. According to [37] charcoal volatile matter varies from a high of at least $40 \%$ to a low of 5\% or even less. Also, [37] noted that prolonging the carbonization of charcoal at a high temperature produces a fuel with a lower volatile matter. When the carbonization heat is low and the retort time is short, then the volatile content rises.

However, [38] reported that biomass fuel with a combination of higher volatile matter and lower moisture percentage is an indicator of charcoal having a better flammable length and combustion properties. [39] also noted that feedstock with lower volatile content would result in inefficient utilization. [26] also observed that feedstock used to produce briquettes usually determines the value of the volatile matter in fuel.

Several studies have proven that the proportion of volatile matter has a strong effect on the burning behavior of fuels [26] [31] [34] [40]. However, a study by [26] that investigated the mango waste briquette reported lower values of volatile matter than in the current study. Also, [34] [36] also observed lower values of

Table 3. Proximate analysis of briquette bounded with cassava, molasses, and the charcoal $(\mathrm{n}=3)$.

\begin{tabular}{|c|c|c|c|c|c|c|c|c|c|c|c|c|}
\hline \multicolumn{13}{|c|}{ Proximate composition of briquettes and charcoal } \\
\hline \multirow{2}{*}{ Treatment $^{y}$} & \multicolumn{3}{|c|}{ Moisture content \% } & \multicolumn{3}{|c|}{ Volatile matter \% } & \multicolumn{3}{|c|}{ Ash content $\%$} & \multicolumn{3}{|c|}{ Fixed carbon content $\%$} \\
\hline & Brq_cas & Brq_mol & char & Brq_cas & Brq_mol & char & Brq_cas & Brq_mol & char & Brq_cas & Brq_mol & char \\
\hline Residential & $3.57 \mathrm{a}$ & $3.37 \mathrm{a}$ & $7.10 \mathrm{ab}$ & 21.1a & $26.3 \mathrm{a}$ & $22.9 \mathrm{a}$ & $55.1 \mathrm{a}$ & $54.0 \mathrm{~b}$ & $5.03 a$ & $20.6 \mathrm{a}$ & $16.3 \mathrm{a}$ & $64.5 \mathrm{a}$ \\
\hline Educational & $3.58 \mathrm{a}$ & $4.13 \mathrm{~b}$ & $5.97 \mathrm{a}$ & $23.9 \mathrm{a}$ & $30.0 \mathrm{a}$ & $19.6 \mathrm{a}$ & $41.5 \mathrm{a}$ & $36.7 \mathrm{a}$ & $5.38 \mathrm{a}$ & $30.0 \mathrm{a}$ & $28.7 \mathrm{c}$ & $69.0 \mathrm{a}$ \\
\hline Market & $4.32 \mathrm{a}$ & $4.65 c$ & $8.12 \mathrm{~b}$ & $20.8 \mathrm{a}$ & $28.9 \mathrm{a}$ & $23.4 \mathrm{a}$ & $53.1 \mathrm{a}$ & $42.5 \mathrm{a}$ & $5.82 \mathrm{a}$ & $22.7 \mathrm{a}$ & $24.5 \mathrm{~b}$ & $63.0 \mathrm{a}$ \\
\hline
\end{tabular}

$\mathrm{y}$, Means with the same letter, columns wise, indicate no significant difference $(\mathrm{p} \leq 0.05)$ columns wise. Where, ${ }^{\star} \mathrm{Char}=\mathrm{charcoal},{ }^{\star} \mathrm{Brq} \_\mathrm{cas}=\mathrm{cassava}$ binder briquette, ${ }^{*}$ Brq_ $\mathrm{mol}=$ molasses binder briquette, $\mathrm{n}=$ number of replicate per sample. 
volatile matter in briquettes produced from rice husk and tannery waste than this study's findings. Also, [40] reported that briquette fuel with a higher volatile matter had a better burning efficiency. This was observed in educational and market waste briquettes bound with molasses which had higher volatile matter than briquettes bound with cassava. According to [34], briquettes usually use more energy to burn off the volatile matter in fuel before heat energy is released for the intended purpose. Therefore these briquettes which had comparatively high volatile matter would use more energy to burn off the volatile mater as opposed to charcoal that had a lower volatile matter. Generally, a high percentage of volatile matter is an indicator of low fixed carbon content. However, the recommended values of volatile matter for domestic cooking fuel range between $20 \%$ and $30 \%$ with the marginal acceptable value of about $40 \%$ [41]. Therefore, the organic waste briquettes made with cassava binder and molasses binder were within the recommended value hence showing that these briquettes can be good for domestic use.

\subsubsection{Ash Content}

The ash content of the different briquettes and charcoal are shown in Table 3. The quantity of ash (55.1\%) that had remained after the incineration of organic waste briquette bound with cassava binder from residential waste was the greatest followed by the briquettes made with molasses binder (54\%) while the lowest was observed in charcoal (5.03\%). One-way ANOVA showed that there was a significant difference $(\mathrm{p}<0.05)$ in ash content between the different briquettes and charcoal. However, there was no significant difference $(p>0.05)$ in the ash content of the different briquettes. Similar studies by [26] [42] [43] reported lower percentage ash content in briquettes than the current finding. However, [42] noted that feedstocks types and binders used could have had a great effect on the ash content of the briquettes.

[44] [45] reported that low ash content of briquette was an indicator of a high calorific value of a fuel. Also, [42] [46] observed that the higher the ash content of the feedstock, the lower the burning rate as well as the heating value of the fuel. Furthermore, the higher ash content may cause problems in handling and disposal or during the cooking time because the ash may block the air holes and eventually lower the oxygen supply in the combustion chamber of the cooking stove [47]. Several studies recommend that the ash content should be $3 \%$ to $4 \%$ for good quality briquettes [48] [49]. In this regard, the briquettes produced may not qualify to be very desirable.

[50] however noted that the construction industry may benefit from the high ash content of the organic waste briquettes. This is because ash of briquettes can be used for stabilization of soil, road base and manufacture of bricks among others. However, the contaminants such as heavy metals may impede the potential use of this ash in the soil. According to [28], the recommended heavy metal composition in briquettes fuel or charcoal range from 6.07 to $8.03 \mathrm{mg} / \mathrm{kg}$ for copper, $10 \mathrm{mg} / \mathrm{kg}$ is the maximum value for lead and cadmium ranged from 0.33 
to $0.95 \mathrm{mg} / \mathrm{kg}$. The values obtained were within the acceptable limits for lead and cadmium in organic waste feedstock used for briquette but copper content was higher. Hence, its use in soil may not be recommended.

\subsubsection{Fixed Carbon Content}

Table 3 also shows a summary of the fixed carbon content of the different briquettes and charcoal. One-way ANOVA test showed that there was a significant difference $(\mathrm{p}<0.05)$ between fixed carbon content of briquettes and charcoal. Overall charcoal had the highest fixed carbon content (69.0\%) compared to the briquettes produced $(16.3 \%$ and $30.0 \%)$. Also, there was a significant difference $(\mathrm{p}<0.05)$ in the fixed carbon content among the briquettes from various dumpsites with briquettes from education institutions having higher fixed carbon content $30.0 \%$ compared to briquettes from other places. Studies by [26] [39] reported higher fixed carbon content in briquettes that varied between $65 \%$ to $81 \%$. These values are greater than this study's findings. Several studies recommended that acceptable fixed carbon content required for biomass fuel applications is about $80.5 \%$ [49]. However, the values obtained for fixed carbon in this study are below the recommended percentage. Therefore, the organic waste briquettes produced would not be fit as a good carbon fuel. However, the low carbon content in briquettes is an indication of good fuel for domestic energy applications.

[16] [50] [51] also observed lower fixed carbon content of briquette produced from rice husk varieties which ranged between $14.8 \%$ and $20.1 \%$. The values they obtained are lower than this study's finding. According to [49] briquettes with lower fixed carbon tend to be harder, heavier and burn easier than briquettes with high fixed carbon. Therefore, this study suggests that the organic waste bounded with cassava binder and molasses binders are suitable for the production of briquettes that are harder, heavier and easy to burn.

\section{Conclusion and Recommendations}

This study assessed the concentration of heavy metal in municipal organic waste, a potential feedstock for domestic fuel briquette production in Kampala city. The findings from this study indicate that the concentration of heavy metals investigated was below the allowable limits while mercury was not detected. This implies that MSW from dumpsites sampled did not pose a health hazard arising from the presence of such heavy metals. Therefore, organic wastes are safe and can be used for briquette production. However, given the rather low calorific values of the briquettes produced, different ways of harnessing energy content of the waste should be investigated. Also, further research is needed to examine for the presence of the other heavy metals in the municipal waste not investigated in this study before it can be declared health hazard free.

\section{Acknowledgements}

The Norwegian Programme for Capacity Development in Higher Education and 
Research for Development (NORHED) under the project Regional Capacity Building for Sustainable Natural Resource Management and Agricultural Improvement under Climate Change (CAPSNAC) is acknowledged for the financial support towards the research project. CAPSNAC teams both at Makerere University and the University of Juba are also acknowledged for the administrative support and academic guidance.

\section{Conflicts of Interest}

The authors declare no conflicts of interest regarding the publication of this paper.

\section{References}

[1] Ziraba, A.K., Haregu, T.N. and Mberu, B. (2016) A Review and Framework for Understanding the Potential Impact of Poor Solid Waste Management on Health in Developing Countries. Archives of Public Health, 74, 55. https://doi.org/10.1186/s13690-016-0166-4

[2] Kinobe, J.R. (2015) Assessment of Urban Solid Waste Logistics Systems: The Case of Kampala, Uganda. Vol. 2015, Swedish University of Agricultural Sciences, Uppsala.

[3] Komakech, A.J., Banadda, N., Kinobe, J.R., Kasisira, L., Gebresenbet, G. and Vinnerås, B. (2014) Characterization of Municipal Waste in Kampala, Uganda. Air and Waste Management Association, 64, 340-348. https://doi.org/10.1080/10962247.2013.861373

[4] Madinah, N., Boerhannoeddin, A., Noriza, R. and Raja, B. (2014) Division Solid Waste Generation and Composition in Kampala Capital City Authority, Uganda: Trends and Management. IOSR Journal of Environmental Science, Toxicology, 8, 57-62. https://doi.org/10.9790/2402-081035762

[5] Kakembo, F. and Rhodah, N.N. (2014) Developing Incentives and Capacity for Sustainable Waste Reuse in Uganda.

[6] Bamuwamye, M., Ogwok, P., Tumuhairwe, V., Eragu, R., Nakisozi, H. and Ogwang, P.E. (2017) Human Health Risk Assessment of Heavy Metals in Kampala (Uganda) Drinking Water. Food Research, 6, 6-16. https://doi.org/10.5539/jfr.v6n4p6

[7] Miito, G.J. and Banadda, N. (2016) Waste to Energy Technologies for Solid Waste Management: A Case Study of Uganda. Agricultural Engineering International: CIGR Journal, 18, 136-146.

[8] Bello, I.A., Bin Ismail, M.N. and Kabbashi, N.A. (2016) Solid Waste Management in Africa: A Review. International Journal of Waste Resources, 6, 1-4. https://doi.org/10.4172/2252-5211.1000216

[9] Bredenhann, L. (1998) Minimum Requirements for the Handling, Classification and Disposal of Hazardous Waste. Department of Water Affairs Forestry, Pretoria.

[10] Mboowa, D., Banadda, N., Kiggundu, N., Kabenge, I. and Komakech, A.J. (2015) Estimation of Methane Generation Based on Anaerobic Digestion and Mass Balance at Kiteezi Landfill, Kampala, Uganda. African Journal of Environmental Science, 9 , 741-746. https://doi.org/10.5897/AJEST2015.1922

[11] UBOS (2016) The National Population and Housing Census 2014-Main Report. Uganda Bureau of Statistics, Kampala.

[12] Omulo, G., Willett, S., Seay, J., Banadda, N., Kabenge, I. and Zziwa, A. (2017) Cha- 
racterization of Slow Pyrolysis Wood Vinegar and Tar from Banana Wastes Biomass as Potential Organic Pesticides. Sustainable Development, 10, 81-92. https://doi.org/10.5539/jsd.v10n3p81

[13] Aransiola, E.F., Oyewusi, T.F., Osunbitan, J.A. and Ogunjimi, L.A.O. (2019) Effect of Binder Type, Binder Concentration and Compacting Pressure on Some Physical Properties of Carbonized Corncob Briquette. Energy Reports, 5, 909-918. https://doi.org/10.1016/j.egyr.2019.07.011

[14] Esakku, S., Palanivelu, K. and Joseph, K. (2003) Assessment of Heavy Metals in a Municipal Solid Waste Dumpsite. Workshop on Sustainable Landfill Management, Chennai, 3-5 December 2003, 139-145.

[15] Zheljazkov, V.D. and Nielsen, N.E. (1996) Studies on the Effect of Heavy Metals $(\mathrm{Cd}, \mathrm{Pb}, \mathrm{Cu}, \mathrm{Mn}, \mathrm{Zn}$ and $\mathrm{Fe}$ ) Upon the Growth, Productivity and Quality of Lavender (Lavandula angustifolia Mill.) Production. Essential Oil Research, 8, 259-274. https://doi.org/10.1080/10412905.1996.9700612

[16] Olupot, P., Candia, A., Menya, E. and Walozi, R. (2016) Characterization of Rice Husk Varieties in Uganda for Biofuels and Their Techno-Economic Feasibility in Gasification. Chemical Engineering Research Design, 107, 63-72. https://doi.org/10.1016/j.cherd.2015.11.010

[17] Kasimbazi, E.B. (2012) Environmental Regulation of Oil and Gas Exploration and Production in Uganda. Energy Natural Resources Law, 30, 185-221. https://doi.org/10.1080/02646811.2012.11435291

[18] Okure, M.A., Musinguzi, E., Wabwire, A. and Bagenda, S. (2014) Experience from Rural Electrification in Uganda: A Case Study of a Husk Powered System in Tiribogo Village.

[19] Liu, A., Ren, F., Lin, W.Y. and Wang, J.Y. (2015) A Review of Municipal Solid Waste Environmental Standards with a Focus on Incinerator Residues. International Journal of Sustainable Built Environment, 4, 165-188. https://doi.org/10.1016/j.ijsbe.2015.11.002

[20] Yabe, J., Ishizuka, M. and Umemura, T. (2010) Current Levels of Heavy Metal Pollution in Africa. Veterinary Medical Science, 72, 1257-1263. https://doi.org/10.1292/jvms.10-0058

[21] Dalahmeh, S., Tirgani, S., Komakech, A.J., Niwagaba, C.B. and Ahrens, L. (2018) Per- and Polyfluoroalkyl Substances (Pfass) in Water, Soil and Plants in Wetlands and Agricultural Areas in Kampala, Uganda. Science of the Total Environment, 631, 660-667. https://doi.org/10.1016/j.scitotenv.2018.03.024

[22] Nabulo, G., Origa, H.O., Nasinyama, G.W. and Cole, D. (2008) Assessment of Zn, $\mathrm{Cu}, \mathrm{Pb}$ and $\mathrm{Ni}$ Contamination in Wetland Soils and Plants in the Lake Victoria Basin. International Journal of Environmental Science Technology, 5, 65-74. https://doi.org/10.1007/BF03325998

[23] Hogervorst, J., Plusquin, M., Vangronsveld, J., Nawrot, T., Cuypers, A., Van Hecke, E., Staessen, J.A., et al. (2007) House Dust as Possible Route of Environmental Exposure to Cadmium and Lead in the Adult General Population. Environmental Research, 103, 30-37. https://doi.org/10.1016/j.envres.2006.05.009

[24] Adelekan, B. and Alawode, A. (2011) Contributions of Municipal Refuse Dumps to Heavy Metals Concentrations in Soil Profile and Groundwater in Ibadan Nigeria. Applied Biosciences, 40, 2727-2737.

[25] Muwanga, A. and Barifaijo, E. (2006) Impact of Industrial Activities on Heavy Metal Loading and Their Physico-Chemical Effects on Wetlands of Lake Victoria Basin (Uganda). African Journal of Science Technology, 7, 51-63. 
https://doi.org/10.4314/ajst.v7i1.55197

[26] Oyelaran, O.A., Bolaji, B.O., Waheed, M.A. and Adekunle, M.F. (2015) Performance Evaluation of the Effect of Waste Paper on Groundnut Shell Briquette. International Journal of Renewable Energy Development, 4, 95-101. https://doi.org/10.14710/ijred.4.2.95-101

[27] Katimbo, A., Kiggundu, N., Kizito, S., Kivumbi, H.B. and Tumutegyereize, P. (2014) Potential of Densification of Mango Waste and Effect of Binders on Produced Briquettes. Agricultural Engineering International: CIGR Journal, 16, 146-155.

[28] Oladeji, J. (2015) Theoretical Aspects of Biomass Briquetting: A Review Study. Energy Technologies Policy, 5, 72-81.

[29] Mitchual, S.J., Frimpong-mensah, K. and Darkwa, N.A. (2014) Evaluation of Fuel Properties of Six Tropical Hardwood Timber Species for Briquettes. Journal of Sustainable Bioenergy Systems, 4, 1-9. https://doi.org/10.4236/jsbs.2014.41001

[30] Komakech, A.J. (2014) Urban Waste Management and the Environmental Impact of Organic Waste Treatment Systems in Kampala, Uganda. Vol. 2014.

[31] Zabaleta, I., Rohr, M., Zermin, F. and Rajabu, H.M. (2016) Slow Pyrolysis of Urban Biowaste in Tanzania-An Analysis of the Technical and Socio-Economic Potential. In: Proceedings of the Sixth International Symposium on Energy from Biomass and Waste, CISA, Dar Es Salaam, 1-18.

[32] Bandara, W. and Kowshayini, P. (2017) Evaluation of the Performances of Biomass Briquettes Produced with Invasive Eichornia Crassipes (Water Hyacinth), Wood Residues and Cow Dung for Small and Medium Scale Industries. Fundam Renewable Energy and Applications, 8, 1-8.

[33] Matúš, M., Križan, P., Šooš, L. and Beniak, J. (2015) Effects of Initial Moisture Content on the Physical and Mechanical Properties of Norway Spruce Briquettes. International Journal of Environmental and Ecological Engineering, 9, 1227-1233.

[34] Onuegbu, T., Ilochi, N.O., Ogbu, I.M., Obumselu, F.O. and Okafor, I. (2012) Preparation of Environmental Friendly Bio-Coal Briquette from Groundnut Shell and Maize Cob Biomass Waste: Comparative Effects of Ignition Time and Water Boiling Studies. Current Research in Chemistry, 4, 110-118. https://doi.org/10.3923/crc.2012.110.118

[35] Oyelaran, O.A., Balogun, O., Ambali, A.O. and Abidoye, J.K. (2017) Characterization of Briquette Produced from Tannery Solid Waste. Materials Engineering Structures, 4, 79-86.

[36] Mohlala, L.M., Bodunrin, M.O., Awosusi, A.A., Daramola, M.O., Cele, N.P. and Olubambi, P.A. (2016) Beneficiation of Corncob and Sugarcane Bagasse for Energy Generation and Materials Development in Nigeria and South Africa: A Short Overview. Alexandria Engineering Journal, 55, 3025-3036. https://doi.org/10.1016/j.aej.2016.05.014

[37] Suryaningsih, S., Nurhilal, O., Yuliah, Y. and Salsabila, E. (2018) Fabrication and Characterization of Rice Husk Charcoal Bio Briquettes. AIP Conference Proceedings, 1927, Article ID: 030044. https://doi.org/10.1063/1.5021237

[38] FAO (1985) Industrial Charcoal Making. In: Wood Carbonization and the Products It Yield, FAO, Rome, 1-20.

[39] Arellano, G.M.T., Kato, Y.S. and Bacani, F.T. (2105) Evaluation of Fuel Properties of Charcoal Briquettes Derived from Combinations of Coconut Shell, Corn Cob and Sugarcane Bagasse. DLSU Research Congress, Manila, 2-4 March 2015, 1-6.

[40] Hasan, E.S., Jahiding, M., Mashuni, Ilmawati, W.O.S., Wati, W. and Sudiana, I.N. 
(2017) Proximate and the Calorific Value Analysis of Brown Coal for High-Calorie Hybrid Briquette Application. Journal of Physics. Conference Series, 846, Article ID: 012022. https://doi.org/10.1088/1742-6596/846/1/012022

[41] Gbabo, A., Alake, A. and Efomah, S.A. (2015) Assessment of the Performance of a Disc Actuated Briquette Production Machine Developed at the National Cereals Research Institute, Badeggi. Global Journal of Engineering Science and Research Management, 2, 125-134.

[42] Lohri, C.R., Rajabu, H.M., Sweeney, D.J. and Zurbrügg, C. (2016) Char Fuel Production in Developing Countries-A Review of Urban Biowaste Carbonization. Renewable Sustainable Energy Reviews, 59, 1514-1530. https://doi.org/10.1016/j.rser.2016.01.088

[43] Onukak, I.E., Mohammed-Dabo, I.A., Ameh, A.O., Okoduwa, S.I.R., Fasanya, O.O., Adamu, I.K. and Ejila, A. (2017) Production and Characterization of Biomass Briquettes from Tannery Solid Waste. Recycling, 2, 17. https://doi.org/10.3390/recycling2040017

[44] Byamugisha, G.R., Byaruhanga, J.K. and Kariko-buhwezi, B. (2015) Characteristics of Ten Selected Ugandan Bio-Wastes under Ultimate Analysis for Briquettes Production. International Journal of Scientific Engineering and Research, 3, 11-20.

[45] Borowski, G., Stępniewski, W. and Wójcik-Oliveira, K. (2017) Effect of Starch Binder on Charcoal Briquette Properties. International Agrophysics, 31, 571. https://doi.org/10.1515/intag-2016-0077

[46] Ana, G.R. and Fabunmi, V.T. (2016) Energy Efficiency Evaluation from the Combustion of Selected Briquettes-Derived Agro-Waste with Paper and Starch Binders. International Journal of Sustainable Green Energy, 5, 71-79.

[47] Thabuot, M., Thanchanok Pagketananga, K.P., Mongkuta, P. and Wongwicha, P. (2015) Effect of Applied Pressure and Binder Proportion on the Fuel Properties of Holey Bio-Briquettes. Energy Procedia, 79, 890-895. https://doi.org/10.1016/j.egypro.2015.11.583

[48] James, A.K., Thring, R.W., Rutherford, P.M. and Helle, S.S. (2013) Characterization of Biomass Bottom Ash from an Industrial Scale Fixed-Bed Boiler by Fractionation. Energy Environment Research, 3, 21. https://doi.org/10.5539/eer.v3n2p21

[49] Gebresas, A., Asmelash, H., Berhe, H. and Tesfay, T. (2015) Briquetting of Charcoal from Sesame Stalk. Energy, 2015, Article ID: 757284. https://doi.org/10.1155/2015/757284

[50] Zubairu, A. and Gana, S.A. (2014) Production and Characterization of Briquette Charcoal by Carbonization of Agro-Waste. Energy Power, 4, 41-47.

[51] James, A.K., Thring, R.W., Helle, S. and Ghuman, H.S. (2012) Ash Management Review-Applications of Biomass Bottom Ash. Energies, 5, 3856-3873. https://doi.org/10.3390/en5103856 